\title{
Kearifan Lokal Masyarakat Kampung Wisata Kerajinan Tangan di Dusun Rejoso Kota Batu
}

\author{
Baskoro Azis \\ ${ }^{1}$ Magister Arsitektur, Universitas Brawijaya \\ Jl. MT. Haryono No. 165, Malang, Indonesia 65145.
}

\begin{abstract}
Abstrak
Kata kunci: Kearifan Lokal, Ekonomi, Kerajinan, Tradisi Budaya

Kearifan lokal yang baru pada masyarakat Jawa di Dusun Rejoso terbentuk dari penyesuaian kearifan lokal yang lama tehadap globalisasi yang salah satunya berdampak ke ekonomi. Dampak globalisasi menyebabkan segala aspek kehidupan terpengaruhi, sistem ekonomi, budaya dan lingkungan hidup manusia. Hal tersebut menyebabkan kearifan lokal yang berlaku dalam masyarakat mulai terkikis. Masyarakat memiliki tradisi yang dikenal sebagai ada kedaerahan (kearifan lokal) yang merupakan symbol kebangsaan, akan tetapi hampir tidak lagi makna yang berarti di era globalisasi. Tujuan utama dari kajian ini adalah mendeskripsikan kearifan kampung kerajinan tangan di Dusun Rejoso. Penelitian kearifan lokal menggunakan metode kualitatif dengan wawancara dan dan survey melui pendekatan studi naratif yaitu penceritaan kembali cerita tentang pengalaman individu, atau progresif-regresif, di mana peneliti memulai dengan suatu peristiwa penting dalam kehidupan sang partisipan. Pengumpulan datanya dilakukan dengan wawancara mendalam dan observasi kemudian dianalisis untuk mendapatkan gambaran dan kesimpulan yang dapat menjawab permasalahan dan mencapai tujuan penelitian. Dusun Rejoso secara langsung dan tak langsung memunculkan identitas dan tradisi baru dan berjalan dengan tradisi yang lama secara beriringan. Terbentuknya kearifan lokal yang baru dari dampak globalisasi yaitu Home Industry karena untuk menaikkan taraf hidup warga.
\end{abstract}

Keywords:

Local Wisdom,

Economy, Crafts,

Cultural

Traditions

\section{Abstract}

The recent local wisdom of Java society in Rejoso hamlet has been formed by the adjustment of old local wisdom toward the globalization in which one of them had impact in economy. The impacts of globalization have caused all aspects of life affected including economic system, culture and human environment. Those have caused the prevailing local wisdom in community beginning to erode. Society has a tradition which is known as the regional existing (local wisdom) that is the national symbol, but hardly becoming importance in the globalization era. The main objective of this study is to describe the wisdom of handicraft village in Rejoso Hamlet. The research of local wisdom used the qualitative methods including interview and survey through narrative study approach namely retelling the story of an individual's experience, or progressive-regressive, where the researcher began with an important event in the participants' life. Data collection has been done by in-depth interviews and observation and continued to analyse for getting an overview and conclusion that can address the concern problems and achieve the research purposes. Rejoso hamlet directly and indirectly reveals the new identity and tradition and walking with an old tradition side by side. The formation of a new local wisdom of the globalization impacts is Home Industry which is to improve the standard of society life. 


\section{PENDAHULUAN}

Kearifan lokal di Indonesia saat ini menjadi topik bahasan menarik dibicarakan di tengah semakin menipisnya sumber daya alam dan peliknya upaya pemberdayaan masyarakat. Perubahan kehidupan seseorang berdasarkan ide pemikiran dan idealis yang berada disetiap orang karena kebutuhan individual yang kuat. Hal ini juga dikemukakan oleh Barnabid (2002) aspek epistemologi dari idealisme adalah pengetahuan hendaknya bersifat ideal dan spritual yang dapat menuntun kehidupan manusia pada kehidupan yang lebih mulia.

Pengaruh perubahan tersebut berdampak juga pada gaya hidup yang menjadi sebuah tradisi. Berawal dari pemikiran untuk menaikan taraf hidup menjadikan sebuah tradisi lama mengalami perubahan secara perlahan. Dampak globalisasi menyebabkan segala aspek kehidupan terpengaruhi, misalnya sistem ekonomi, budaya dan lingkungan hidup manusia. Hal tersebut menyebabkan kearifan lokal yang berlaku dalam masyarakat mulai terkikis. Masyarakat memiliki tradisi yang dikenal sebagai ada kedaerahan (kearifan lokal) yang merupakan symbol kebangsaan, akan tetapi hampir tidak lagi makna yang berarti di era globalisasi.

Menurut Sartini (2004) kearifan lokal merupakan idealis warga yang berada di area wilayahnya yang bersifat dianggap benar, sakral, bernilai positif yang berakar dan penduduk sekitar mengikutinya. Menurut data pada Kementerian Sosial kearifan lokal diartikan sebagai pandangan hidup dan pengetahuan serta berbagai strategi kehidupan yang berwujud aktivitas yang dilakukan oleh masyarakat lokal dalam menjawab berbagai masalah dalam pemenuhan kebutuhan mereka.

Sistem pemenuhan kebutuhan mereka pasti meliputi seluruh unsur kehidupan, agama, ilmu pengetahuan, ekonomi, teknologi, organisasi sosial, bahasa dan komunikasi, serta kesenian.
Pengertian lain yang senada tentang kearifan lokal menurut Zulkarnain dan Febriamansyah (2008) adalah berupa prinsip-prinsip dan cara-cara tertentu yang dianut, dipahami, dan diaplikasikan oleh masyarakat lokal dalam berinteraksi dan berinterelasi dengan lingkungannya dan ditransformasikan dalam bentuk sistem nilai dan norma adat.

Kearifan lokal dibangun dari nilai-nilai sosial yang dijunjung dalam struktur sosial masyarakat sendiri dan memiliki fungsi sebagai pedoman, pengontrol, dan rambu-rambu untuk berperilaku dalam berbagai dimensi kehidupan baik saat berhubungan dengan sesama maupun dengan alam. Eksistensi kearifan lokal semakin memudar pada permukiman masyarakat. Salah satunya dalam bidang pertanian dengan tingkat kebutuhan hidup yang tinggi menjadikan penduduk sekitar melakukan perubahan terhadap pekerjaan untuk menunjang taraf hidup ekonomi penduduk.

Dengan adanya kearifan lokal merupakan pandangan dan pengetahuan tradisional yang menjadi acuan dalam berperilaku dan telah diaplikasikan secara turun-temurun untuk memenuhi kebutuhan dan menjawab permasalahan dalam kehidupan suatu masyarakat. Kearifan lokal memberikan identitas, fungsi dan makna dalam masyarakat menyesuaikan keberadaan penduduk setempat, menjawab problema yang terjadi serta memberikan pengetahuan dan cara bertahan hidup untuk menanggapi lingkungan yang berkembang.

Munculnya globalisasi yang muncul berupa Home Industry sendiri di peruntukkan bagi pengusaha kecil yang dikelola oleh keluarga. Untuk meningkatkan taraf hidup dan eksistensi masyarakat yang semakin modern warga berusaha untuk mencari penghasilan lebih dikarenakan tuntutan akan keuangan untuk bertahan hidup dan gaya hidup lebih modern.

Kriteria Home Industry berada dalam UU No 9 Tahun 1995 adalah: milik WNI, berdiri sen- 
diri, berafiliasi langsung atau tidak langsung dengan usaha menengah atau besar dan berbentuk badan usaha perorangan, baik berbadan hukum maupun tidak. Home Industri juga dapat berarti industri rumah tangga, karena termasuk dalam kategori usaha kecil yang dikelola keluarga.

Sebagaimana nama kegiatan ekonomi ini, Home Industry pada umumnya memusatkan kegiatan di sebuah rumah keluarga tertentu dan biasanya para karyawan berdomisili di tempat yang tak jauh dari rumah produksi tersebut. Karena secara tidak langsung hubungan kekerabatan menjadi faktor utama Home Industry (pemilik usaha dan karyawan), memungkinkan untuk menjalin komunikasi sangat mudah. Dari kemudahan dalam berkomunikasi ini diharapkan dapat memicu etos kerja yang tinggi. Karena masing-masing merasa bahwa kegiatan ekonomi ini adalah milik keluarga, kerabat dan juga warga sekitar. Merupakan tanggung jawab bersama dalam upaya meningkatkan perusahaan mereka.

Bertambahnya jumlah keluarga tentu saja akan menambah jumlah kebutuhan dalam memenuhi keperluan anggota keluarga itu sendiri semakin meningkat. Kebutuhan keluarga ini akan terasa ringan terpenuhi jika ada usaha yang mendatangkan income atau penghasilan keluarga untuk menutupi kebutuhan tersebut. Home Industri yang pada umumnya berawal dari usaha keluarga yang turun menurun dan pada akhirnya meluas ini secara otomatis dapat bermanfaat menjadi mata pencaharian penduduk kampung di sekitarnya. Kegiatan ekonomi ini biasanya tidak begitu menyita waktu, sehingga memungkinkan pelaku usaha membagi waktunya untuk keluarga dan pekerjaan tetap yang ditekuni.

Bagaimana pengaruh Home Industry terhadap kearifan lokal setempat? Banyaknya nilai dan budaya masyarakat yang mengalami perubahan dengan cara meniru atau menerapkannya modernisasi di segala bidang kehidupan, menyebab- kan kearifan lokal yang tumbuh dan berkembang di dalam masyarakat menjadi terkikis. Misalnya terjadi perubahan ciri kehidupan masyarakat desa yang tadinya syarat dengan nilai-nilai gotong royong menjadi individual. Selain itu juga banyak yang mengikuti nilai-nilai budaya luar yang dapat terjadi dehumanisasi yaitu derajat manusia nantinya tidak dihargai karena lebih banyak menggunakan mesin-mesin berteknologi tinggi.

Dengan hadirnya usaha atau pekerjaan baru tidak hanya kearifan lokal yang berubah dari segi ekonomi tetapi juga merubah lingkungannya dan menjadikan identitas warga setempat. Dusun Rejoso Desa Junrejo Kota Batu merupakan salah satu dusun yang warganya bekerja sebagai petani dan sebagian beralih menjadi pekerja Home Industry kerajinan cobek dan kayu. Bagaimana kearifan lokal yang terbentuk adanya faktor ekonomi dan karakter setempat dampak adanya Home Industry tersebut?

\section{Permasalahan}

Bagaimanakah kearifan lokal yang terbentuk pada kampung kerajinan tangan kayu dan cobek Dusun Rejoso Di Kota Batu?

\section{Lokasi Penelitian}

Lokasi penelitian berada di Dusun Rejoso, Desa Junrejo, Kota Batu. Berada di dekat jalan utama antar kota Malang dan kota Batu. Jarak dari kota Malang ke lokasi sekitar sekitar 40 menit jika menggunakan mobil. Untuk memasuki dusun ini dapat dilalui melalui kendaraan roda empat dan roda dua, aksesibilitas lebih muda dijangkau karena jalanannya sudah beraspal dengan sekitar lebih 4-5 meter. Ciri - ciri ketika berada di dusun ini adanya sawah dan didepan rumahnya terdapat tumpukan kayu atau hasil kerajinan di bagian teras rumah. 
Sejarah Dusun awalnya masih secara global sebelum adanya Home Industry. Berdasarkan laporan pelacakan sejarah Junrejo yang dilakukan Ulul Azmi, S. Ag wartawan Batu Pos yang ditugaskan ke Museum Nasional menyebutkan bahwa Junrejo berasal dari kata DYON - REJTO atau JUNWATU. Dalam bahasa kuno artinya Tempat Air (Gentong Jawa) sehingga DYON - REJTO atau arca DYON WATU yang sekarang ada di museum nasional bisa bermakna tempat air dari batu. Menurut sumber yang ada di museum nasional keberadaan JUN tersebut sejak abad IX atau masa Kerajaan Tumapel / Singosari, sehingga dari uraian sejarah tersebut lahirlah nama JUNREJO. Sedangkan kronologis perkembangan dari tahun ke tahun hingga akhir berdirinya Kecamatan Junrejo sebagai berikut:

Tahun 1914 di Desa JUNWATU yang ketika itu Kepala Desa bernama Pak Marsih, ditemukan benda berupa JUN sedangkan di Desa Telogorejo ditemukan Telogo yang menurut masyarakat disebut JEDING dalam bahasa jawa.
Tahun 1922 Desa Telogorejo diubah menjadi Desa Jeding dengan pendukuhan Rejoso.

Tahun 1923 Desa Junwatu, Jeding dan Rejoso digabung menjadi satu dengan nama JUNREJO dan yang dipercaya menjadi Kepala Desa pada saat itu adalah Kepala Desa dari Junwatu yakni Pak Marsih sampai beliau meninggal dunia.

Tahun 1937 yang menjadi Kepala Desa Junrejo adalah Pak Duriyat, yang ketika itu diangkat melalui pemilihan dan beliau menjabat hingga tahun 1974.

Tahun 1993 merupakan hari yang bersejarah bagi Kecamatan Junrejo karena merupakan hari lahir Kecamatan Junrejo yang bersamaan dengan lahirnya Kota Administratif Batu. Kecamatan Junrejo dibagi menjadi 7 Desa/ Kelurahan, antara lain: 1. Desa Torongrejo, 2. Desa Beji, 3. Desa Junrejo, 4. Desa Tlekung, 5. Desa Mojorejo, 6. Desa Pendem, 7. Kelurahan Dadaprejo.

Atas persetujuan para tokoh masyarakat di kecamatan junrejo maka Desa Junrejo ditetapkan sebagai Ibukota Kecamatan yang Kantor Kecamatan Junrejo bertempat di Desa Junrejo.

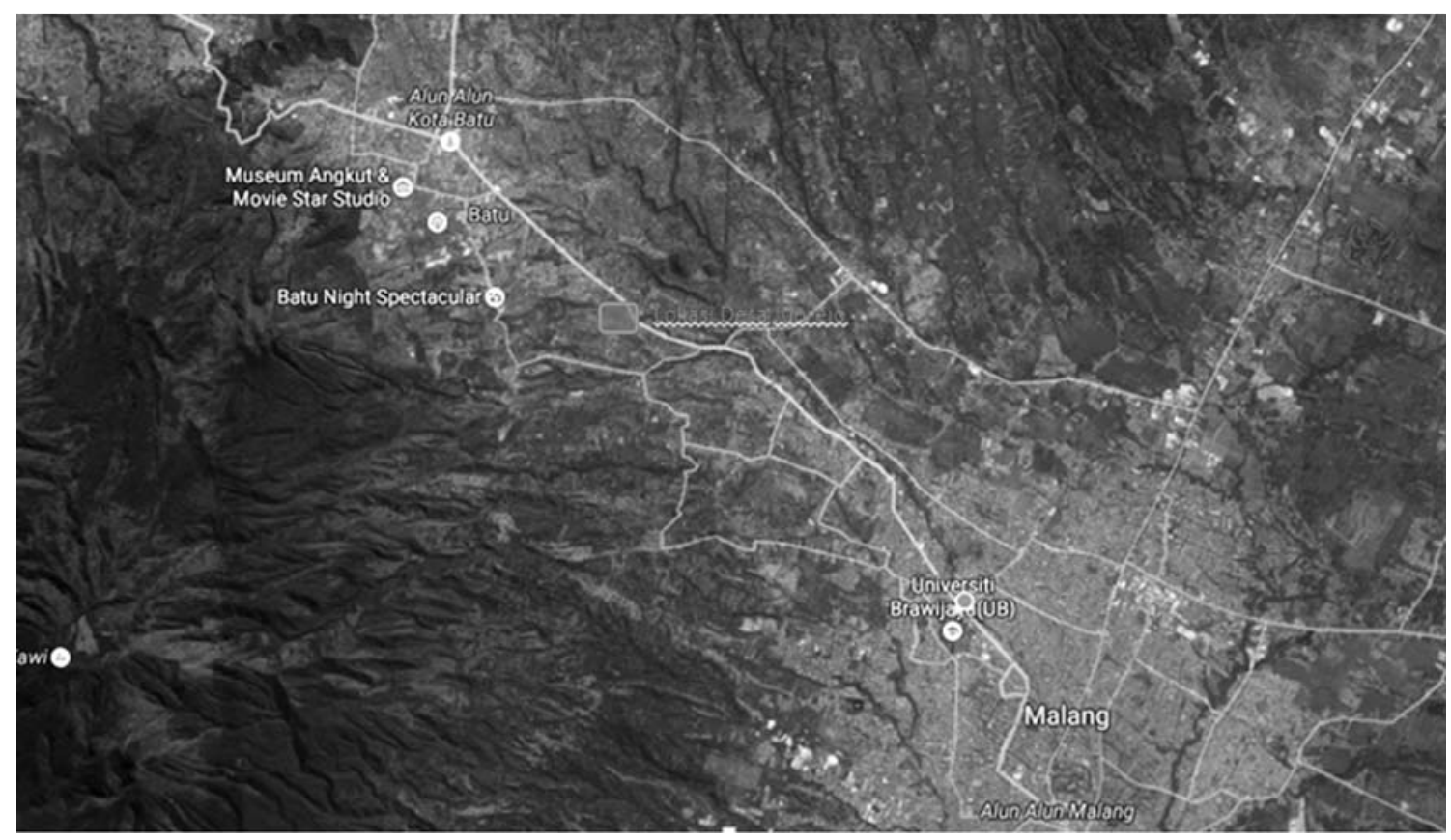

Gambar 1 Lokasi Desa Junrejo (Sumber: maps.google.com) 


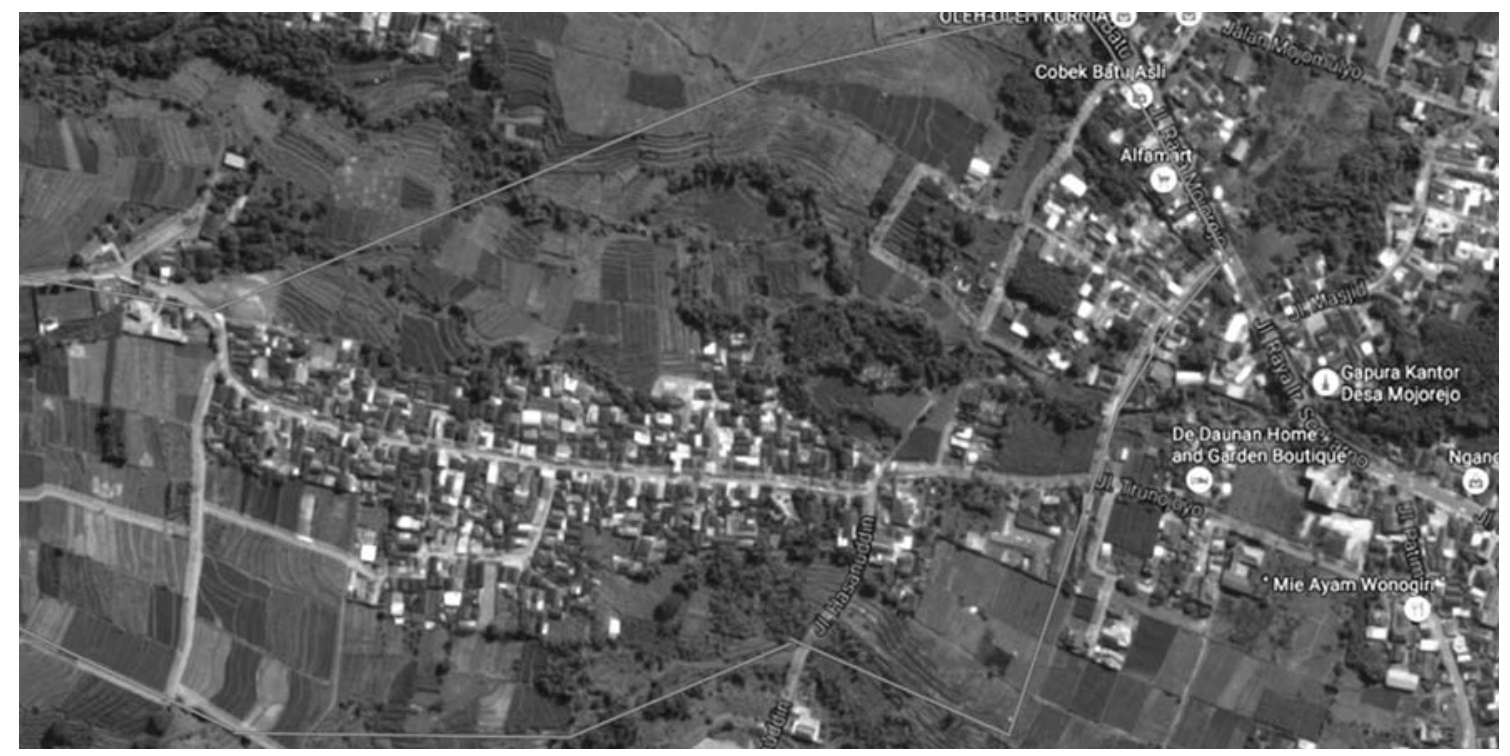

Gambar 2 lokasi Dusun Rejoso (Sumber: maps.google.com)

\section{KEARIFAN LOKAL PADADUSUN REJ OSO}

Pada tahun 1965 dengan 6 pendiri bersaudara dengan satu orang yang "kreatif" yaitu Bapak Sujak (orang kreatif), Bapak Kasdi, Bapak Sofyan, Bapak Sukadi, Bapak Kasun, dan Bapak Samanu. Ke 6 bersaudara tersebut awalnya adalah buruh dan petani di desa setempat dengan keadaan ekonomi kebawah. Lalu dilandasi oleh Bapak Sujak untuk membuat sebuah kerajinan rumah tangga dengan peralatan manual dan membawa perekonomian yang lebih maju. Penduduk yang awalnya keseluruhan petani dan buruh sekitar $80 \%$ menjadi pengerajin kayu karena faktor ekonomi yang dinilai dapat memenuhi kebutuhan hidup, Home Industry yang didirikan merupakan dorongan juga dari warga sekitar yang merupakan keluarga penduduk, kekerabatan di dusun ini merupakan keluarga dari besar dari 6 pendiri ini sehingga sumber daya manusia yang ada di utamakan dari warga sekitar yang merupakan kerabat - keluarganya.

Sekitar tahun 1980 terbentuk sebuah paguyuban yang merupakan wadah pengerajin untuk usaha yang ditekuni. Selain itu, kerajinan tangan berupa cobek, telenan dan uleg - uleg merambah kerajinan tas ayaman dan souvenir dari kayu dan awal sebelum tahun 1980 kerajinan sekitar masih menggunakan kayu dari lingkungan sekitar sampai akhirnya didukung sumber daya oleh perhutani untuk bahan kayu. Pada tahun 1990 mendapatkan bantuan dari pemerintah berupa mesin bubut sehingga warga tidak bersusah payah menggunakan peralatan manual dan mempermudah pekerjaan dari segi jumlah dan tenaga. Beranjak setahun setelahnya $80 \%$ warga sudah menguasai kerajinan kayu dan dijuluki kampung kerajinan kayu.

Di tahun 2000 Dusun Rejoso ini menyandang gelar Kampung Wisata Kerajinan Kayu. Ditahun ini dari $80 \%$ pengerajin menurun menjadi $50 \%$ karena saingan pendiri pekerjaan dan 30\% warga yang lainnya menjadi pekerja di pengerajin kayu yang sukses.

Ruang lingkup spasial dalam penelitian ini terbagi secara mikro, meso dan makro. Ruang lingkup mikro meliputi pemanfaatan ruang terbuka untuk kerajinan (workshop). Pada lingkup meso dan makro meliputi penataan cluster rumah warga dan aktivitas warga dan acara-acara tertentu.

Ruang terbentuk dikarenakan aktivitas keseharian masyarakat menjadi ruang sosial (Indeswari et al., 2013). 


\section{Kearifan Lokal Pada Skala Mikro}

\section{A. Gender Space}

Pembagian teritori ruang berdasarkan jenis kelamin dapat dilihat dari pekerjaan yang terdapat pada area workshop. Pembagian ini berdasarkan pengalaman selama ada pelatihan dari luar yang menjadi tradisi warga setempat. Pada area workshop terdapat tempat pressing kayu, tempat membubut, finishing kasar, finishing halus, pengecatan dan packing.

Nasruddin Nawir (2014) berpendapat bahwa dimana zona yang yang lebih cenderung ditempati sudah ditentukan serta dimanfaatkan oleh kaum hawa adalah bagian hunian dalam, sedangkan yang dominan dimanfaatkan serta diatur sepenuhnya oleh laki-laki adalah bagian kolong rumah, sawah atau kebun. Pemanfaatan ruang, baik ruang dalam rumah ataupun kolong rumah, sawah dan kebun (ruang luar) sangat dipegaruhi oleh profesi yang berimplikasi pada waktu-waktu penggunaan ruang. Profesi sebagai petani oleh lakilaki secara kodrati lebih banyak melakukan kegiatan di luar rumah serta melakukan aktifitas dari pagi hingga sore hari. Sedangkan profesi sebagai Ibu rumah tangga lebih banyak menghabiskan waktu di rumah. Hal ini berbeda dengan pada kam- pung wisata kerajinan, pada area workshop, pressing kayu, tempat membubut, finishing kasar dan pengecatan dilakukan oleh pekerja laki - laki sedangkan finishing halus, dan packing dilakukan oleh pekerja perempuan. Para pekerja merupakan kerabat-keluarga dari pemilik workshop kerajinan kayu dan cobek. Sehingga secara tak langsung juga menjadi ruang bersama warga.

\section{B. Pola Ruang Workshop}

Tidak lepas dari kearifan lokal setempat, pola ruang pekerja juga merupakan dampak dari tradisi dan penanganan warga setempat untuk kenyamanan dan keselamatan pekerjanya. Perletakan tempat untuk pressing kayu terdapat diarea tengah bagian bawah dan untuk temapt membubut (memotong dan membentuk) kayu menjadi kerajinan terdapat dibagian pojok serta berada di kontur bagian bawah. Dan bagian untuk finishing kasar dan halus berada pada bagian sisi samping pembubutan, sedangkan pengecatan berada pada bagian tengah ruangan dan packing berada bagian depan dari area workshop atau di teras depan rumah. Penataan atau pola yang terbentuk terjadi dibeberapa tempat karena terlatih menyesuaikan kondisi lingkungan sehingga menjadi "standar" pola ruang oleh warga di Dusun Rejoso itu sendiri.

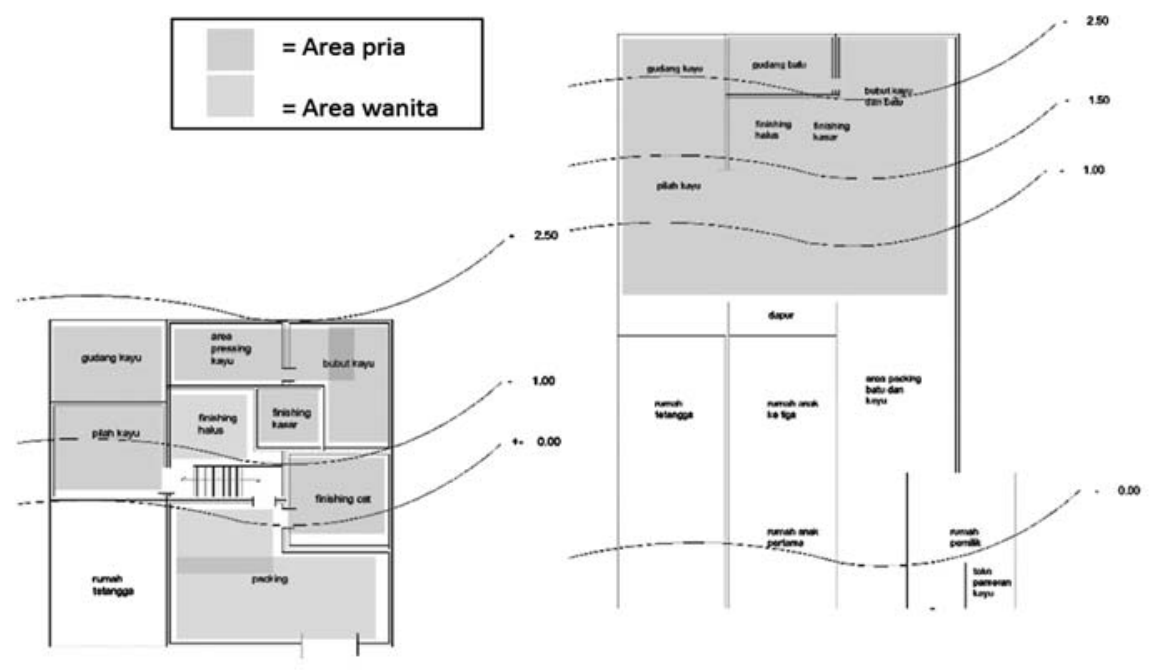

Gambar 3. Pola ruang dan gender space workshop 1 (kiri) dan workshop 2 (kanan) (Sumber: Survey) 


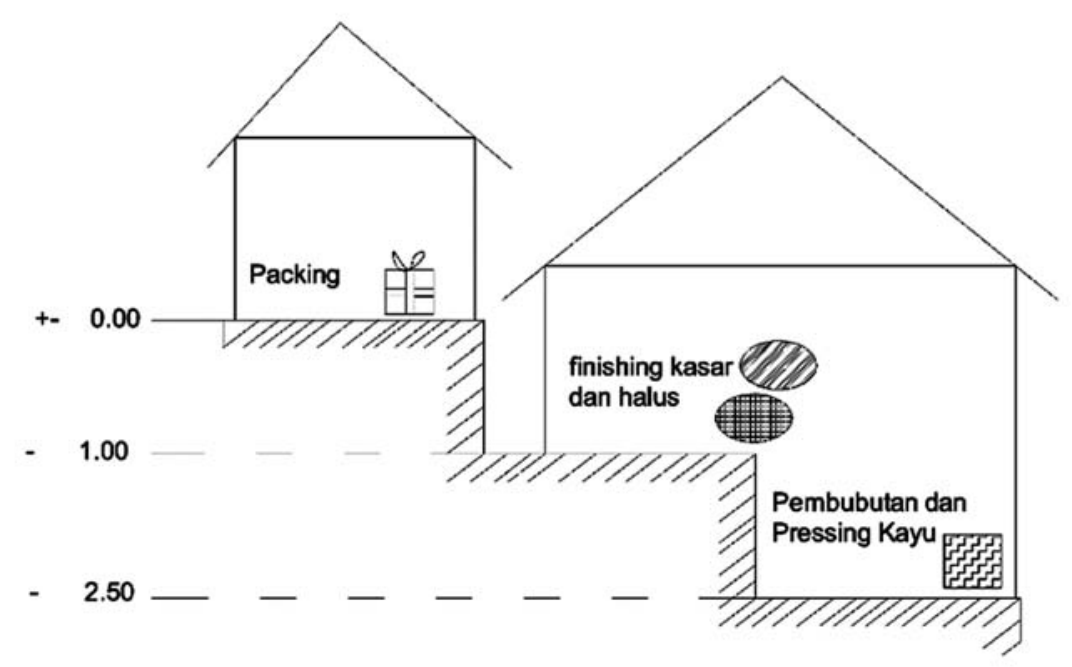

Gambar 4. gambar potongan workshop 1 (Sumber : Survey)

Pola aktivitas pada workshop 1

Pria dan wanita:

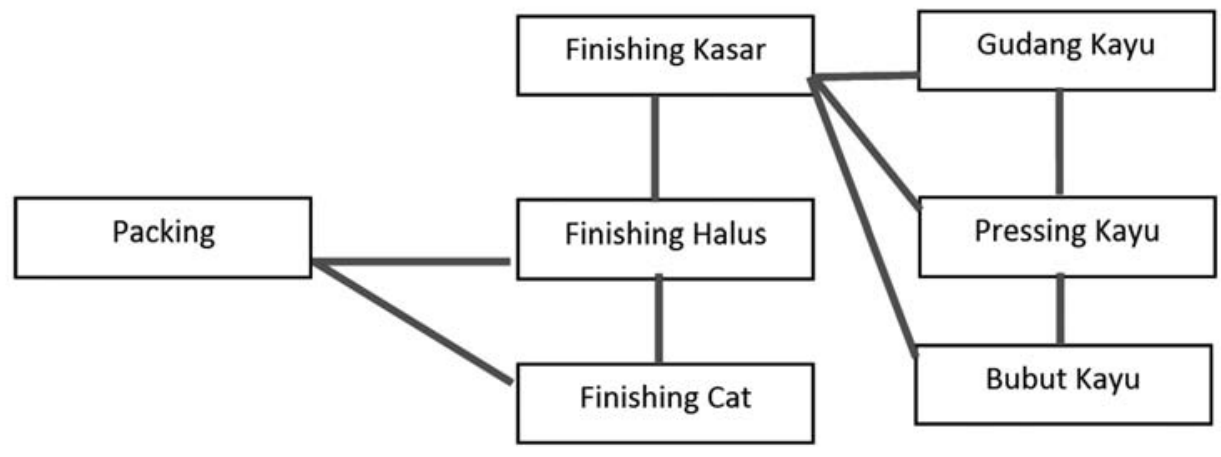

1. Pria melakukan cek stock di gudang

2. Melakukan pressing kayu untuk membentuk bongkahan kayu berbentuk kubus atau balik.

3. Membubut kayu hasil pressing menyerupai bentuk yang setengah jadi.

4. Hasil setengah jadi dibawa ke finishing kasar untuk di perhalus bentukan kasarnya.

5. Setelah finishing kasar selesai, tugas wanita pun dimulai untuk memperhalus dengan amplas karena wanita dinilai lebih tekun dan cekatan. Menurut Andreas Sukamto (2014) Keterbatasan perempuan dalam pendidikan dan umur menyebabkan perempuan mau be- kerja pada semua jenis pekerjaan dan umumnya bekerja disektor informal. Meningkatnya peluang kerja bagi perempuan di sektor industri dikarenakan oleh beberapa hal. Pertama, dalam memasuki usaha tersebut tidak menuntut jenjang pendidikan yang tinggi. Kedua, kondisi yang dituntut oleh tenaga kerja perempuan lebih ringan dari tenaga kerja lakilaki.

Sehingga wanita dapat bekerja dan berpenghasilan yang cukup untuk membantu rumah tangga dan bekerja dengan kuantitas pekerjaan yang adil. 
6. Lalu pada bagian pengecatan adalah pria karena banyak zat yang dapat mengganggu pernapasan, sehingga beralih ke tugas pria.

7. Terakhir, wanita mempacking hasil pekerjaan tangan setelah pengecatan selesai dengan membungkus menggunakan plastik atau kardus.
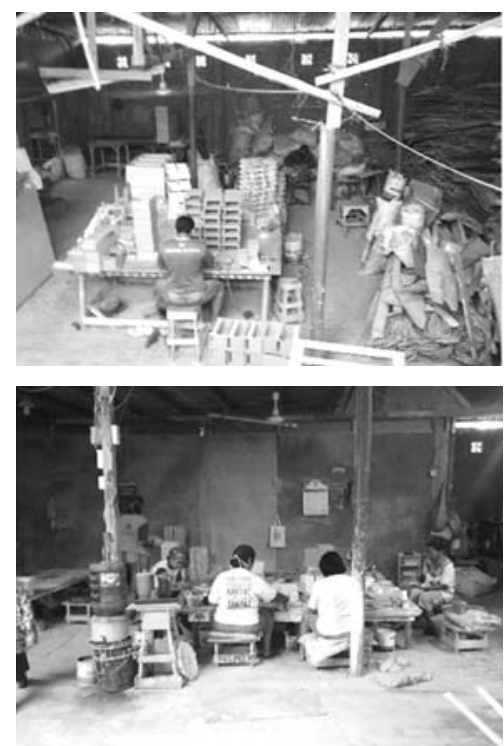

Gambar 5. gambar bubut-finishing kasar (kiri) dan finishing halus (kanan) (Sumber: Survey)
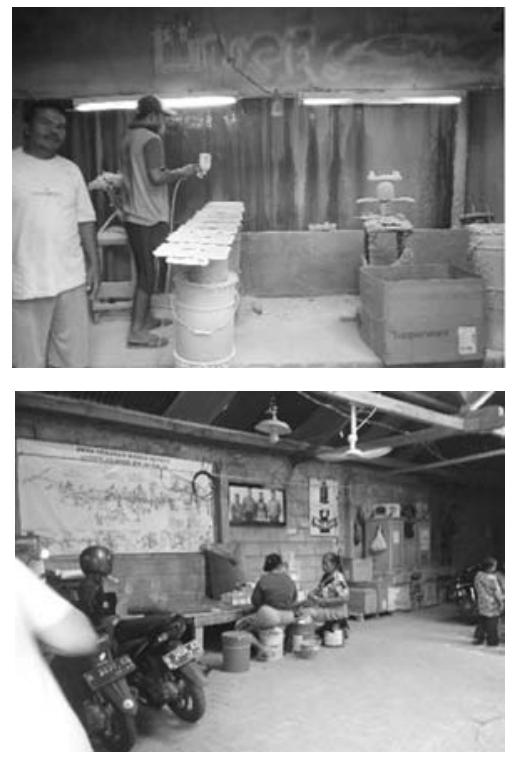

Gambar 6. gambar pengecatan (kiri) dan packing (kanan) (Sumber: Survey)
Pola workshop ke dua merupakan tempat kayu dan batu cobek. Pekerjaan disini lebih cenderung di para lelaki. Bagaimana dengan wanita? Pekerjaan wanita berada pada bagian packing di bagian depan rumah.

\section{Biyodo}

Biyodo adalah tradisi acara bantu membantu ketika ada sanak saudara atau tetangga mendapati acara pernikahan di rumah sendiri. Hal ini sudah menjadi tradisi lama di dusun ini karena berdasarkan sistem kekerabatan.

\section{Brobosan}

Brobosan, kegiatan menerobos ini dilakukan ketika upacara kematian. Jenazah di angkat lalu keluarga terdekat melewati peti di bawahnya berputar sebanyak tiga kali searah jarum jam. Sebelum jenazah di bawa ke kuburan, biasanya para keluarga terdekat melakukan tradisi brobosan. Hal ini dipercaya agar keluarga yang ditinggalkan melupakan kesedihan dan menjadi bentuk penghormatan terakhir kepada yang meninggal. (Aphilia, 2015)

\section{E. Sosial - Ekonomi}

Penerus kerajinan adalah anak sendiri, orang tua yang memiliki anak tunggal diwajibkan untuk meneruskan usaha orang tuanya. Orang tua yang memiliki anak lebih dari satu anak pertama tetap diwajibkan melanjutkan usaha orang tua, sedangkan anak bungsu dibebaskan dalam memilih pekerjaan akan tetapi tetap harapan orang tua untuk membuka lapangan kerja yang searah dengan pekerjaan orang tuanya. Penerus kerajinan akan tetap di berlakukan karena jaman modern dan perkembangan teknologi. Pada generasi baru semakin maju sehingga hubungan antar keluarga atau kerabat semakin renggang. 
Menurut Hoffman (1973:26) nilai anak berkaitan dengan fungsi anak kepada orang tua atau kebutuhan orang tua yang terpenuhi. Keberadaan anak dalam keluarga berfungsi sebagai penyambung garis keturunan, penerus tradisi keluarga, curahan kasih sayang, hiburan dan jaminan hari tua. Arnold (1975) mengatakan bahwa orang tua di desa lebih menitikberatkan manfaat ekonomi dan kegunaan cepat guna (termasuk tunjangan hari tua) dari anak tersebut. Sebagaimana orang tua di desa telah membiasakan anak ikut serta membantu orang tua untuk bekerja di sawah sendiri atau bekerja untuk membantu keuangan keluarga maupun bekerja dengan mendapatkan upah dari orang lain.

Sehingga garis keturunan yang ada meneruskan pekerjaan dari orang tuanya dengan pekerjanya adalah tetangganya yang merupakan kerabatnya (keluarga) sendiri. Karena perekonomian yang semakin sulit didapat menurut orang tua terhadap anak akan lebih mudah jika meneruskan usaha keluarga. Faktor lainya juga berupa pengaruh globalisasi yang muncul karena ruang bersama yang hilang dapat terjalin kembali melalui kerajinan tangan.

\section{Kearifan Lokal Pada Skala Makro}

\section{A. Penataan Pola dan Cluster Rumah}

Penataan pola dan cluster pada rumah adalah memanjang mengikuti jalan utama dusun. Perkembangan pola rumah ini berdasarkan sistem kekerabatan yang awalnya secara horisontal dari timur ke arah barat mengikuti jalan utama sehingga berkembang selama adanya Home Industry secara vertikal, hal ini ada kesamaan dengan tanean lajhang suku permukiman Madura akan tetapi berbeda, setiap anaknya yang menikah akan dibangunkan rumah disekitar rumah orang tua tetapi tidak memiliki pola seperti suku permukiman Madura.
Soekandar Wiriaatmadja (1972) membagi pola pemukiman di pedesaan ke dalam empat pola, yakni:

a. Pola permukiman menyebar,

Rumah-rumah para petani tersebar berjauhan satu sama lain. Pola ini terjadi karena belum adanya jalan-jalan besar, sedangkan orangorang harus mengerjakan tanahnya secara terus menerus. Dengan demikian, orang-orang tersebut terpaksa harus bertempat tinggal di dalam lahan mereka.

b. Pola permukiman memanjang

Bentuk pemukiman yang terlentak di sepanjang jalan raya atau di sepanjang sungai, sedangkan tanah pertaniannya berada di belakang rumahnya masing-masing.

c. Pola permukiman berkumpul

Bentuk pemukiman di mana rumah-rumah penduduk berkumpul dalam sebuah kampung, sedangkan tanah pertaniannya berada di luar kampung.

d. Pola permukiman melingkar

Bentuk pemukiman di mana rumah-rumah penduduk melingkar mengikuti tepi jalan, sedangkan tanah pertaniannya berada di belakangnya.

Hal ini lebih cenderung dengan sistem kekerabatan di Jawa yang pola permukimannya yaitu memanjang. Pada pola permukiman ini sudah terjadi juga sebelum adanya Home Industry dan sampai sekarang masih diterapkan. Sehingga pemakaian RTH dan sawah sebagian menjadi rumah warga karena perkembangan yang merupakan sistem kekerabatan. Di setiap rumah masih ada yang yang bercocok tanam dengan menggunakan halaman depan atau planter bag sebagai kebun karena dahulu pernah menjadi buruh dan petani karena lebih murah daripada harus membeli dipasar. 


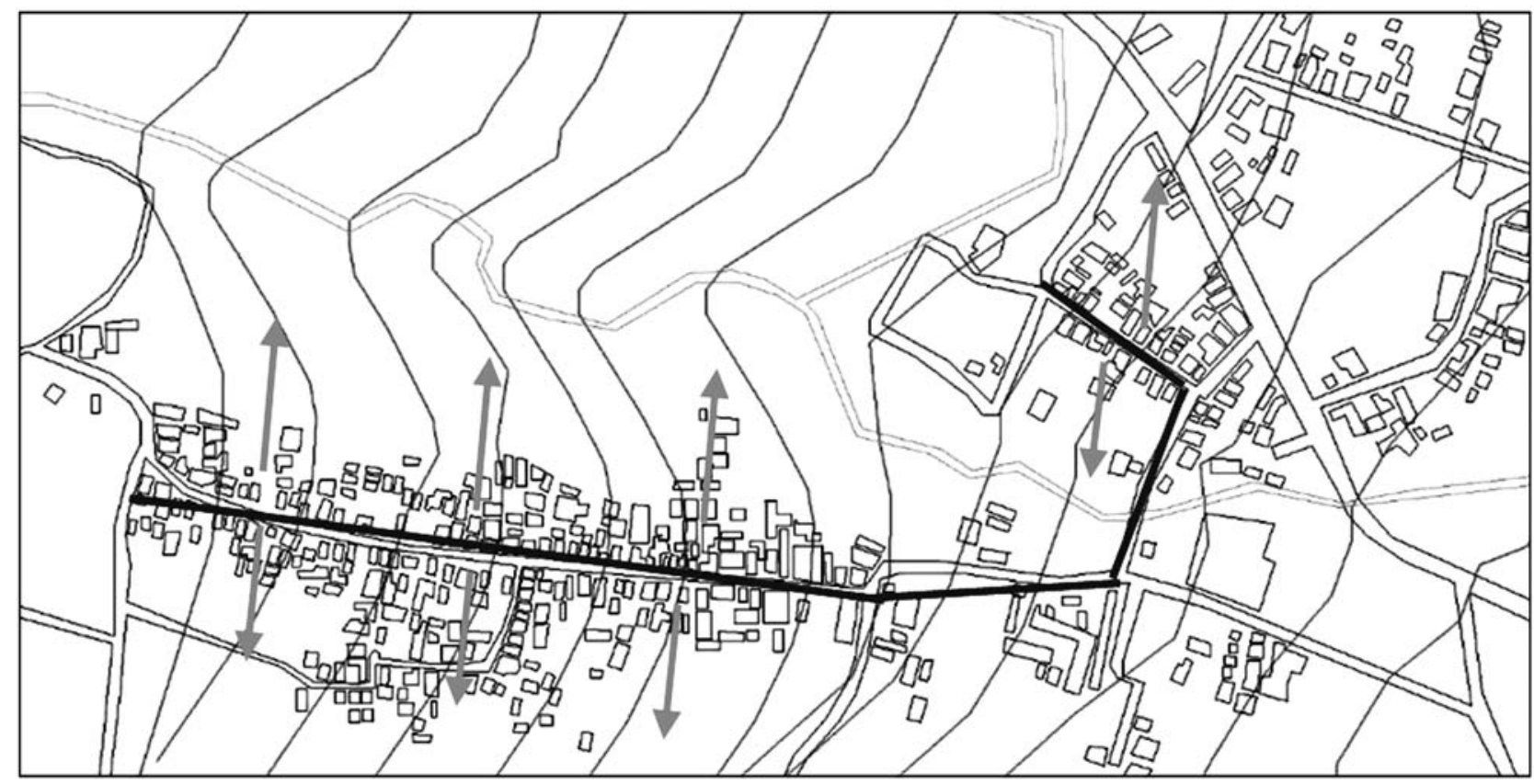

Gambar 7. Peta Kontur Dusun Rejoso dan Cluster (Sumber: Dokumen Pribadi)

\section{B. Bersih Dusun dan Sedekah Bumi}

Bersih Dusun dilakukan untuk tolak bala dan menjauhkan roh jahat. Warga dusun berbondong - bondong membawa makanan dari masing masing keluarga untuk di doakan lalu dibagikan ke warga kembali pelaksanaan dilakukan di pelataran masjid. Sedekah bumi sendiri untuk memperingati rasa syukur warga kepada pencipta, kegiatan ini sudah mendasar sebelum munculnya Home Industry. Kegiatan ini dilakukan dengan mengambil sebagian hasil kerja warga lalu di bawa memutari dusun lalu berhenti di pelataran masjid dan di doakan dan di kembalikan kepada warga kembali. Ke dua tradisi tersebut dijadikan satu acara bersama dengan kegiatan 17 Agustus (peringatan hari kemerdekaan) karena sebagian penduduk sibuk karena tuntutan pekerjaan.

\section{Satu Suro dan Jaranan}

Satu suro biasanya diperingati pada malam hari setelah Magrib pada hari sebelum tanggal satu biasanya disebut malam satu suro, hal ini karena pergantian hari Jawa dimulai pada saat matahari terbenam dari hari sebelumnya, bukan pada tengah malam. Untuk sebagian warga pada malam satu suro dilarang untuk ke mana-mana kecuali untuk berdoa ataupun melakukan ibadah. Warga dusun sendiri melakukan pengajian bersama disaat malam satu suro tiba.

Sedangkan Jaranan sendiri adalah seni tari yang dilakukan pemuda untuk menghormati para leluhur di dusun. Acara ini biasanya sering dimainkan pada saat ada acara di bulan suro, acara penyambutan tamu besar, dan festival budaya.

\section{KESIMPULAN}

Kearifan lokal yang terbentuk di Dusun Rejoso merupakan efek dari penyesuaian lingkungan hidup, aktivitas, kebiasaan sehari - hari terhadap dampak pemikiran warga untuk meningkatkan ekonomi dan tanpa disadari menjadi sebuah tradisi yang melekat menjadi bagian kese- 
harian warga. Kearifan lokal yang terdapat pada Dusun Rejoso lebih terlihat secara nyata (berwujud) dan tidak kasat mata. Efek dari Home Industry memberikan dampak yang cukup besar perbuahan dari $100 \%$ penduduknya merupakan buruh dan petani menjadi $50 \%$ penduduknya beralih menjadi pengerajin kayu - batu.

Kearifan lokal yang terbentuk secara nyata munculnya pekerjaan secara tidak sadar dengan adanya perbedaan gender karena kemampuan wanita dan laki - laki, lalu pola ruang workshop yang terbentuk karena pelatihan dan faktor keamanan dan kenyaman, sistem kekeluargaan atau kekerabatan yang terbentuk karena faktor pekerjaan dan mempererat kekerabatan tersebut.

Kearifan lokal yang tak berwujud muncul karena tradisi dari yang menghormati leluhur sampai dengan berhubungan dengan rasa syukur kepada Pencipta, serta tradisi membantu saudara yang menikah karena hubungan kekerabatan, selain itu untuk mempertahankan ekonomi anak dari pemilik kerajinan kayu - batu diwajibkan menjadi penerus usaha orang tuanya dan mempertahankan gelar dan pekerjaan Kampung Wisata Kerajinan.

Dusun Rejoso secara langsung dan tak langsung memunculkan identitas dan tradisi baru dan berjalan dengan tradisi yang lama secara beriringan. Terbentuknya kearifan lokal yang baru dari dampak globalisasi yaitu Home Industry karena untuk menaikkan taraf hidup warga.

\section{Referensi}

Alphilia, Anna. 2015. Upacara Kesripahan Adat Jawa Di Banjarsari, Surakarta. Institut Seni Indonesia: Surakarta.

Arnold F et all. 1975. The Value of Children a CrossNational Study Vol.1 Introduction and Comparative Analysis. Honolulu, Hawaii, East West Population Institute.

Barnadib, Imam., Filsafat Pendidikan, Yogyakarta: Adicita Kaiya Nusa: 2002
Departemen Sosial RI. 2006. Memberdayakan Kearifan Lokal bagi Komunitas Adat Terpencil.

Hoffman LW. 1973. A Psychological Perspective On The Value Of Children to Parents. Concept and Measures dalam J Fawcet (ed) Psychological Perspective on Population.

Ife, Jim. 2002. Community Development : Community based alternatives in an age of globalization. Australia : Pearson Education.

Indeswari, A., Antariksa, Pangarsa, G.W., Wulandari, L.D. (2013). Dinamika dalam pemanfaatan Ruang Bersama Pada Permukiman Madura Madalungan Di Baran Randugading Malang. Arskon Jurnal Arsitektur Dan Kontruksi.

Nasruddin, Nawir. 2014. Aspek Gender Arsitektur Rumah Adat Karampuang Di Kabupaten Sinjai, Sulawesi Selatan. Jurnal Ilmiah Seri Ilmu Teknik. Program Pascasarjana Univ.Hasanuddin: Makassar

Sartini. 2004. Menggali Kearifan Lokal Nusantara: Sebuah Kajian Filsafat., Jurnal Filsafat.

Sukamto, Andreas. 2014. KONTRIBUSI PEKERJA PEREMPUAN TERHADAP PEMBENTUKAN PENDAPATAN KELUARGA; Studi Kasus: Pekerja Perempuan Industri Kerajinan Gerabah di Pedukuhan Kajen, Desa Bangun Jiwo, Kecamatan Kasihan, Kabupaten Bantul, DIY. Universitas Atma Jaya: Yogyakarta.

Triyadi, Sugeng, Iwan Sudradjat dan Andi Harapan. 2010. Kearifan Lokal pada Bangunan Rumah Vernakular di Bengkulu dalam Merespon Gampa; Studi Kasus: Rumah Vernakular di Desa Duku Ulu. Local Wisdom Vol. II, No. 1, hal: 1-7

Wiriaatmadja, S., 1981. Pokok-pokok Sosiologi Pedesaan.Jakarta : C.V. Tasaguna

Zulkarnain, A.Ag., \& Febriamansyah, R. 2008. Kearifan Lokal dan Pemanfaatan dan Pesisir., Jurnal Agribisnis Kerakyatan, 1. 